\title{
ANTIGENS OF PLASMODIUM VIVAX BLOOD STAGE PARASITES IDENTIFIED BY MONOCLONAL ANTIBODIES
}

\author{
JOHN W. BARNWELL
}

Monoclonal antibodies have been obtained that react with antigens of $P$. vivax blood stage parasites and infected erythrocyte membranes. Some define external surface antigens of the merozoite while other appear to be confined to the merozoite rhoptry organelles. Other monoclonal antibodies appear to recognize parasite induced components of the infected erythrocyte membrane.

One monoclonal antibody, 3F8.A2 probably recognizes the merozoite surface glycoprotein of $P$. vivax which is analogous to antigens found in rodent (Holder \& Freeman, 1981), simian (Epstein et al., 1981), and human malaria species, (Holder \& Freeman, 1984). At least three other antigens appear to be on the surface of $P$. vivax merozoites, two of which are of $170 \mathrm{Kd}$ and 140 $\mathrm{Kd}$ in molecular weight as judged by SDS-Page analysis of immunoprecipitates.

Two monoclonals recognize two different antigens both of which appear to be associated with the rhoptry organelles of $P$. vivax. These two antigens are of $160 / 140 \mathrm{Kd}$ and $53 \mathrm{Kd}$.

Five monoclonal antibodies appear as speckles over the infected erythrocyte and recogni. ze two antigens of $95 \mathrm{Kd}$ and $70 \mathrm{Kd}$. These monoclonal antibodies probably recognize parasite antigens in the caveola-vesicular complexes which are associated with the membrane of $P$. vivax infected erythrocytes, (Aikawa, Miller \& Rabbage, 1975).

Analysis by immunofluorescence assay also indicates that all or some of these monoclonal antibodies cross-react with $P$. simium, $P$. cynomolgi and $P$. knowlesi, which may reflect their evolutionary relationship with $P$. vivax. In fact, since all twelve of the monoclonal antibodies crossreact with $P$. simium, it suggests that this species is antigenically closely related with $P$. vivax which may have only in the recent past become adapted to Brazilian monkeys.

Plasmodium vivax is a human malaria parasite species of major importance and of wide distribution. In many areas of the world the prevalence of $P$. vivax exceeds that of $P$. falciparum and the other two human malaria species, $P$. malariae and $P$. ovale. Although, not generally causing a lethal infection, as may be the case in some rapidly evolving $P$. falciparum infections, $P$. vivax infections cause severe morbidity, and malarial fever attacks are frequent due to relapses and reinfection.

There have been very few studies on $P$. vivax blood stage antigens and the available information does not permit us to define those which may be involved in the protective host response. This situation is primarily due to the inability to culture this human malaria species in vitro and is further agrravated by the impossibility to obtain suitable amounts of parasite material from the most frequently used simian host, i.e., Aotus monkeys. We have bypassed the latter difficulty by adapting several strains of $P$. vivax to splenectomized Saimiri monkeys which develop relatively high peak parasitemias of 2 to $10 \%$. The parasite material we have collected from these monkeys was used to immunize mice for the production o monoclonal antibodies in order to characterize $P$. vivax blood stage antigens and to identify potential immunogens.

We have obtained numerous hybridomas which secrete monoclonal antibodies reactive with the blood stage parasites of $P$. vivax. Several of these monoclonal antibodies have been characterized by their stage specificity, the pattern they produce by the immunofluorescence assay (IFA), and relative eletrophoretic mobility of the protein antigens(s) cognized by these monoclonal antibodies. In addition, studies of the cross-reactivities between different isolates of $P$. vivax, and other malaria species have revealed some findings of interest. Table I gives the general characteristics of the monoclonal antibodies and the antigens they recognize.

Five monoclonal antibodies react with mature schizonts and merozoites. These monoclonals, 3F8.A2, 1G5.D9, 4E4.D9, 1E9.D5 and 1C2.F10 when assayed on mature schizonts, all produce an immunofluorescence pattern that rims or circumscribes the outline of the developing or developed merozoites. This suggests a surface membrane or surface coat location for the antigens they recognize. $3 \mathrm{~F} 8$. A2 gives the brightest fluorescent signal at a standard concentration of $10 \mu \mathrm{g}$ of antibody per $\mathrm{ml}$ and also circumscribes the surface of late trophozoites and early devel-

Department of Medical and Molecular Parasitology, New York University School of Medicine, 341 East 25th Street, New York, NY 10010, USA. 
TABLE I

Characteristics of $P$. vivax blood stage antigens detected by a series of monoclonal antibodies

\begin{tabular}{|c|c|c|c|c|c|}
\hline $\begin{array}{l}\text { Monoclonal } \\
\text { Antibody }\end{array}$ & Isotype & $\begin{array}{c}\text { Parasite } \\
\text { Stage } \\
\text { Reactivity }\end{array}$ & $\begin{array}{c}\text { IFA } \\
\text { Pattern }\end{array}$ & $\begin{array}{c}\text { Probable } \\
\text { Location of } \\
\text { Parasite } \\
\text { Antigen }\end{array}$ & $\begin{array}{c}\text { Mr of } \\
\text { Antigen (Kd) }\end{array}$ \\
\hline $3 F 8 . A 2$ & $\lg G_{1}$ & $\mathrm{MZ} / \mathrm{SZ}^{\#}$ & $\begin{array}{l}\text { surface } \\
\text { outline }\end{array}$ & $\begin{array}{l}\text { merozoite } \\
\text { membrane }\end{array}$ & $210^{*}$ \\
\hline 4E4.D9 & $\operatorname{IgG}_{1}$ & $\mathrm{MZ} / \mathrm{SZ}$ & $\begin{array}{l}\text { surface } \\
\text { outline }\end{array}$ & $\begin{array}{l}\text { merozoite } \\
\text { membrane }\end{array}$ & 170 \\
\hline 1G5.D2 & $\lg G_{2}$ & $\mathrm{MZ} / \mathrm{SZ}$ & $\begin{array}{l}\text { surface } \\
\text { outline }\end{array}$ & $\begin{array}{l}\text { merozoite } \\
\text { membrane }\end{array}$ & 140 \\
\hline $1 C 2 . F 10$ & $\operatorname{IgG}_{1}$ & $\mathrm{MZ} / \mathrm{SZ}$ & $\begin{array}{l}\text { surface } \\
\text { outline }\end{array}$ & $\begin{array}{l}\text { merozoite } \\
\text { membrane }\end{array}$ & $\mathrm{ND}^{* *}$ \\
\hline 1E9.D5 & $\operatorname{Ig} G_{1}$ & $\mathrm{MZ} / \mathrm{SZ}$ & $\begin{array}{l}\text { surface } \\
\text { outline }\end{array}$ & $\begin{array}{l}\text { merozoite } \\
\text { membrane }\end{array}$ & ND \\
\hline 4B10.D5 & $\operatorname{Ig} G_{1}$ & $\mathrm{MZ}($ Int. $)$ & punctate & rhoptry & 160 \\
\hline 4E1.D9 & $\operatorname{IgCr}_{1}$ & $\mathrm{MZ}(\operatorname{lnt})$. & punctate & rhoptry & 53 \\
\hline 2H8.D3 & $\lg G_{1}$ & $\begin{array}{c}\text { infected } \\
\text { erythrocyte }\end{array}$ & speckled & $\mathrm{CVC}^{+}$ & 95 \\
\hline $2 \mathrm{H} 12 . \mathrm{B} 4$ & $\operatorname{lgG}_{1}$ & $\begin{array}{l}\text { infected } \\
\text { erythrocyte }\end{array}$ & speckled & $\mathrm{CVC}^{+}$ & 95 \\
\hline 1H4.B6 & $\operatorname{IgG}_{1}$ & $\begin{array}{l}\text { infected } \\
\text { erythrocyte }\end{array}$ & speckled & $\mathrm{CVC}^{+}$ & 95 \\
\hline $4 \mathrm{Cl} 2 . \mathrm{G} 4$ & $\operatorname{Ig}_{1} 1$ & $\begin{array}{l}\text { infected } \\
\text { ery throcyte }\end{array}$ & speckled & $\mathrm{CVC}^{+}$ & 95 \\
\hline $1 \mathrm{~A} 3 . \mathrm{G} 4$ & $\operatorname{IgG}_{1}$ & $\begin{array}{c}\text { infected } \\
\text { erythrocyte }\end{array}$ & speckled & $\mathrm{CVC}^{+}$ & 70 \\
\hline
\end{tabular}

* The 3l:8.A2 antigen metabolically incorporates ${ }^{3} \mathrm{H}$-glucosamine.

+ CVC = caveola-vesicle complexes (Schuffncr's stippling).

\# $\mathrm{MZ}=$ merozoite, $\mathrm{SZ}=$ schizont, Int. = Internal.

** ND = Not determined.

oping schizonts. It precipitates from detergent extracts of biosynthetically labeled schizonts a protein band of 205 to $210 \mathrm{Kd}$. The antigen also incorporates ${ }^{3} \mathrm{H}$-glucosamine biosynthetically which suggests the protein is glycosylated. Mab 1G5.D9 gives a weaker fluorescent signal at $10 \mu \mathrm{g}$ $\mathrm{Ab}$ per $\mathrm{ml}$ and immunoprecipitates a biosynthetically (35S-methionine) labeled protein band of approximately $140 \mathrm{Kd}$. This protein is labile, even with the addition of numerous protease inhibitors into the detergent extract and with careful handling, and breaks down into a few bands of a step-ladder pattem on SDS-Page. 4E4.D9 also gives a fairly strong fluorescent signal circumscribing schizonts and merozoites. The 4E4.09 Mab precipitates a ${ }^{35} \mathrm{~S}$-methionine labeled protein of about $170 \mathrm{Kd}$. This antigen, like the $140 \mathrm{Kd}$ protein defined by Mab 1G5.D2, also, under conditions of limited proteolytic digestion, breaks down into a pattern of numerous bands resembling a 'step-ladder'. If this 'step-ladder' pattern is produced by proteases that recognize specific cleavage sites, it may indicate the presence of repetitive amino acid sequences. The Mabs 1E9.D5 and $1 C 2$.F 10 also give a fluorescent signal which surrounds the merozoite. We have not yet been able to identify the molecular moieties recognized by these monoclonal antibodies, neither by immunoprecipitation, followed by SDS-Page analysis, nor by Western immunoblotting.

Two monoclonal antibodies react with $P$. vivax merozoites by producing a characteristic discrete punctate dot immuno-fluorescence pattern that sometimes is a double dot of fluorescence in a single merozoite. This pattern of staining has been interpreted as an indication that the antigens are localized in the rhoptry organclles of merozoites (Oka et al., 1984). One Mab, 4B 10. D5, immunoprecipitates a ${ }^{3} \mathrm{H}$-leucine labeled doublet of bands of approximately 160 and $140 \mathrm{Kd}$. 4E1.F2 immunoprecipitates a band of approximately $53 \mathrm{Kd}$ which appears to be weakly labeled with ${ }^{3} \mathrm{H}$-histidine or proline. 
Another set of monoclonal antibodies produce a completely different pattern of staining by IFA. These Mabs, 1A3.G4, 2H8.D3, 2H12.B4, 1H4.B6, and 4C 12.G4, produce a staining pattern of small bright speckles or spots of unequal size and intensity over the entire parasitized erythrocyte. This pattern is reminiscent of Schuffner's stippling that is typically present in Giemsa stained thin films of $P$. vivax and vivax-like malaria species. 1A3.G4 immunoprecipitates a $70 \mathrm{Kd}$ ${ }^{35} \mathrm{~S}$-methionine labeled band, whereas the other four monoclonals recognize a $95 \mathrm{Kd}$ band which can be most readily extracted in $0.5-1.0 \%$ SDS and only minimally extracted with the anionic detergent Triton X100. Surface fluorescence occurs with two of these Mabs, 2H8.D3 and 2H12.B4, when combined with unfixed intact suspensions of trophozoite - infected erythrocytes. This suggests the epitope(s) on the $95 \mathrm{Kd}$ protein which are recognized by these two Mabs maybe exposed on the external surface of the eny throcyte, presumably within the caveolar depression.

All the Mab antibodies discussed in this report react not only with the Belem strain used for immunization but also with other isolates of $P$. vivax (North Korean and Thai). A comparison of the cross-reactivity of these monoclonal antibodies with other human or simian malaria species is given in Table II. None of the monoclonal antibodies react with $P$. brasilianum or $P$. falciparum blood stage parasites. Some of the Mabs react with the simian malarias $P$. cynomolgi and $P$. knowlesi However, all the Mabs react with a simian New World malaria species so far found only in some areas of Brazil, $P$. simium. This would suggest a very close evolutionary relationship, if not identity, between $P$. simium and $P$. vivax.

\section{TABLE II}

Reactivity of $P$. vivax blood stage monoclonal antibodies with other human and simian malaria species by immunofluorescence assay

\begin{tabular}{|c|c|c|c|c|c|}
\hline & P. simium & P. cynomolgi & P. knowlesi & P. brasilianum & P. falciparum \\
\hline 3F 8.A 2 & $+++^{*}$ & $+t$ & - & - & - \\
\hline 4E4.D9 & +++ & - & - & - & - \\
\hline 1G5.D2 & $+t$ & + & + & & \\
\hline $1 C 2 . F 10$ & ++ & +++ & $+t$ & - & - \\
\hline 1E9.D5 & +++ & $+t+$ & ++ & - & - \\
\hline 4B10.D5 & $t++$ & - & - & - & - \\
\hline $4 \mathrm{E} 1 . \mathrm{F} 2$ & ++ & - & - & - & - \\
\hline IA3.G4 & +++ & - & - & - & - \\
\hline 2H8.D3 & +++ & - & - & - & - \\
\hline 2H12.B4 & +++ & - & - & - & - \\
\hline $1 \mathrm{H} 4 . \mathrm{B} 6$ & $t+t$ & $++t$ & ++ & - & - \\
\hline \multirow[t]{2}{*}{$4 C 12 . G 4$} & +++ & $t++$ & $t++$ & - & - \\
\hline & $100.0 \%+$ & $50 \%$ & $42 \%$ & 0 & 0 \\
\hline
\end{tabular}

* Increasing number of plus signs indicates the intensity of the fluorescent signal from weak $(1+)$ to strong $(3+)$.

+ Per cent of monoclonal antibodies which react with a particular species of Plasmodium.

\section{REFERENCE}

AIKIWA, M.: MILLER, L.H. \& RABBAGE, J., 1975. Caveola-vesicle complexes in the Plasmalemma of ery throcytes infected by Plasmodium vivax and P. cynomolgi. Am. J. Pathol. 79 (2):285.

EPSTEIN, N.; MILLER, L.H.; KAUSHEL, D.C.; UDEINYA, I.J.: RENFR, J.; HOWARD, R.L.; ASOFSKY, R.; AIKAWA, M. \& HESS, R.L., 1981. Monoclonal antibodies against a specific surface determinant on malarial (Plasmadium knowlesi) merozoites block erythrocyte invasion. J. Immunol., $127: 212.217$.

HOLDER, A.A. \& FREEMAN, R.R., 1981. Immunization against blood stage rodent malaria using purified parasite antigens. Nature, $294: 361-364$

HOLDER, A.A. \& FREEMAN, R.R., 1984. The three major antigens of the surface of the Plasmodium falciparum merozoites are derived from a single molecular weight precursor. J. Exp. Med., I60:621-629.

OKA, M.; AIKAWA, M.; FREEMAN, R.R.; HOLDER, A.A. \& FINF, E., 1984. Litrastructural localization of protective antigens of Plasmodium yoelii merozoites by the use of monoclonal antibodies and ultrathin cryomicrotomy. Am. J. Trop. Med. Hyg., 33 (3) :342-346. 